\section{Multistate Evaluation of Plant Growth and Water Use in Plastic and Alternative Nursery Containers}

\author{
Xueni Wang ${ }^{1}$, R. Thomas Fernandez ${ }^{1,7}$, Bert M. Cregg ${ }^{1}$, \\ Rafael Auras ${ }^{2}$, Amy Fulcher ${ }^{3}$, Diana R. Cochran ${ }^{3}$, Genhua Niu ${ }^{4}$, \\ Youping Sun ${ }^{4}$, Guihong $\mathrm{Bi}^{5}$, Susmitha Nambuthiri ${ }^{6}$, and \\ Robert L. Geneve
}

AdDitionAl INDEX wORDs. keratin, wood pulp, fabric container, coir container, biocontainer, daily water use

SUMMARY. Containers made from natural fiber and recycled plastic are marketed as sustainable substitutes for traditional plastic containers in the nursery industry. However, growers' acceptance of alternative containers is limited by the lack of information on how alternative containers impact plant growth and water use (WU). We conducted experiments in Michigan, Kentucky, Tennessee, Mississippi, and Texas to test plant growth and WU in five different alternative containers under nursery condition. In 2011, 'Roemertwo' wintercreeper (Euonymus fortunei) were planted in three types of \#1 ( $\approx 1$ gal) containers 1) black plastic (plastic), 2) wood pulp (WP), and 3 ) recycled paper (KF). In 2012, 'Green Velvet' boxwood (Buxus sempervirens $\times$ B. microphylla siebold var. koreana) was evaluated in 1) plastic, 2) WP, 3) fabric (FB), and 4) keratin (KT). In 2013, 'Dark Knight' bluebeard (Caryopteris $\times$ clandonensis) was evaluated in 1) plastic, 2) WP, and 3 ) coir fiber (Coir). Plants grown in alternative containers generally had similar plant growth as plastic containers. 'Roemertwo' wintercreeper had high mortality while overwintering in alternative containers with no irrigation. Results from different states generally show plants grown in fiber containers such as WP, FB, and Coir used more water than those in plastic containers. Water use efficiency of plants grown in alternative containers vs. plastic containers depended on plant variety, container type, and climate.

$\mathrm{P}$ lastic is the most commonly used material for containers in nursery and greenhouse operations. Schrader (2013) estimated that the green industry uses over 750 million kilograms of petroleum plastic for containers per year. Plastic containers are lightweight, easy to ship, and inexpensive (Helgeson et al., 2009). However, the disposal of plastic containers has raised concerns about the sustainability of this product. Today, the primary method of plastic container disposal is still in the landfill, and long-term risks of soil and groundwater contamination from ultraviolet light stabilizers and additives used in plastic products are unknown (Hopewell et al., 2009; Teuten et al., 2009). In 2012, 32 million tons of plastic waste were generated; however, only $9 \%$ of the total plastic was recovered for recycling (U.S. Environmental Protection Agency, 2014).

Containers made from various new materials such as bioplastic, coir, poultry feathers, paper fibers, rice hulls, and processed cow manure have emerged as alternative options to plastic containers (Hall et al., 2010; Nambuthiri et al., 2015a). As plant growth is an important factor in growers' consideration when choosing containers, experiments have been carried out to investigate the impact of alternative containers on plant growth. Evans and Hensley (2004) reported that the shoot dry weight of impatiens (Impatiens walleriana) and vinca (Catharanthus roseus) plants in poultry feather containers was greater than that of peat and plastic containers when they were irrigated according to plant need. When the plants received uniform irrigation regardless of container types, vinca had a greater shoot dry weight grown in plastic containers than peat or feather containers, and there was no difference for impatiens. Lopez and Camberato (2011) evaluated poinsettia (Euphorbia pulcherrima) growth in alternative and plastic containers, finding poinsettia grown in molded fiber had better growth compared with wheat starchderived bioresins and plastic containers when irrigated as necessary with water-soluble fertilizer. Kuehny et al. (2011) found that 'Score Red' geranium (Pelargonium $\times$ hortorum) had the greatest shoot growth in 5 -inch plastic containers compared with bioplastic and rice straw containers when they were irrigated as necessary.

Since growers are also pressured to evaluate WU with increasing demand, regulation, and cost of water (Beeson et al., 2004; Koeser et al., 2013), research has compared WU in alternative and plastic containers. Evans and Hensley (2004) found that when vinca and impatiens were irrigated according to plant needs, plants grown in poultry feather and peat containers required more irrigation than that of plastic containers. Koeser et al. (2013) evaluated plant growth and WU for nine different alternative containers. Findings from their research suggest the more porous containers (wood fiber, manure, and straw) required higher irrigation amounts and produced smaller plants. McCabe et al. (2014) found the WU efficiency of 'Rutgers' tomato (Solanum lycopersicum) grown in paper-fiber containers with two coats of polyurethane was greater than that grown in paper-fiber containers with one coat of polyurethane and uncoated containers.

This research expands on past efforts to evaluate suitability of alternative

\begin{tabular}{llll}
\hline $\begin{array}{l}\text { Units } \\
\begin{array}{l}\text { To convert U.S. to SI, } \\
\text { multiply by }\end{array}\end{array}$ & U.S. unit & SI unit & $\begin{array}{l}\text { To convert SI to U.S., } \\
\text { multiply by }\end{array}$ \\
\hline 10 & $\%$ & $\mathrm{~g} \cdot \mathrm{L}^{-1}$ & 0.1 \\
29.5735 & $\mathrm{fl} \mathrm{oz}$ & $\mathrm{mL}$ & 0.0338 \\
0.3048 & $\mathrm{ft}$ & $\mathrm{m}$ & 3.2808 \\
3.7854 & $\mathrm{gal}$ & $\mathrm{L}$ & 0.2642 \\
2.54 & inch $(\mathrm{es})$ & $\mathrm{cm}$ & 0.3937 \\
25.4 & inch $(\mathrm{es})$ & $\mathrm{mm}$ & 0.0394 \\
0.4536 & $\mathrm{lb}$ & $\mathrm{kg}$ & 2.2046 \\
1 & $\mathrm{mmho} / \mathrm{cm}$ & $\mathrm{mS} \cdot \mathrm{cm}^{-1}$ & 1 \\
0.9072 & ton $(\mathrm{s})$ & $\mathrm{Mg}$ & 1.1023 \\
$\left({ }^{\circ} \mathrm{F}-32\right) \div 1.8$ & ${ }^{\circ} \mathrm{F}$ & ${ }^{\circ} \mathrm{C}$ & $\left({ }^{\circ} \mathrm{C} \times 1.8\right)+32$ \\
& & &
\end{tabular}


and plastic containers by comparing them in five states. The objectives of this research were to assess plant growth and biomass in alternative and plastic containers under different nursery environments. In addition, we evaluated the WU characteristics of three woody ornamental plants in alternative and plastic containers under outdoor nursery conditions.

\section{Material and methods}

Site SPECIFICATION AND EXPERIMENTAL DESIGN. This research was conducted at Michigan (lat. $42.7^{\circ} \mathrm{N}$, long. $84.5^{\circ} \mathrm{W}$, elevation 866 ft), Kentucky (lat. 38.1 ${ }^{\circ} \mathrm{N}$, long. 84 . $5^{\circ} \mathrm{W}$, elevation $1043 \mathrm{ft}$ ), Mississippi (lat. $32.0^{\circ} \mathrm{N}$, long. $90.3^{\circ} \mathrm{W}$, elevation $489 \mathrm{ft}$ ), and Texas (lat. $31.7^{\circ} \mathrm{N}$, long. $106.3^{\circ} \mathrm{W}$, elevation $3737 \mathrm{ft}$ ) during 2011-13. Tennessee (lat. $35.9^{\circ} \mathrm{N}$, long. $83.9^{\circ} \mathrm{W}$, elevation $896 \mathrm{ft}$ ) joined the experiment in 2013. A one factor completely randomized experimental design was used. Each container type (treatment) was randomly assigned to one of three irrigation zones (replicate). Within each irrigation zone, there were 15 containers (sub replicate). Containers were spaced 10 inches apart and located in the middle of the irrigation

Mention of a trademark, proprietary product, or vendor does not constitute a guarantee or warranty of the product by the authors or their respective institutions and does not imply their approval to the exclusion of other products or vendors that may also be suitable.

This project was supported by the USDA National Institute of Food and Agriculture, hatch project numbers MICL02010, KY011032, TEN00406, MIS2 11090, TEX09045, and USDA Specialty Crops Research Initiative Grant number 2010-01190. The authors appreciate the financial support provided by Michigan State University Project GREEEN with matching resources from University of Kentucky, University of Tennessee, Mississippi State University, and Texas A\&M System.

The authors appreciate the in-kind support of plants, substrate and fertilizer from Spring Meadow Nursery, Renewed Earth, Harrell's, and Western Pulp Products. Adam Ingrao is also acknowledged for his assistance with data collection.

${ }^{1}$ Department of Horticulture, Michigan State University, 1066 Bogue Street, Room A216, East Lansing, MI 48824

${ }^{2}$ School of Packaging, Michigan State University, 448 Wilson Road, East Lansing, MI 48824

${ }^{3}$ Department of Plant Sciences, University of Tennessee, Knoxville, TN 37996

${ }^{4}$ Texas A\&M AgriLife Research and Extension Center, El Paso, Texas A\&M University, TX 79927

${ }^{5}$ Department of Plant and Soil Sciences, Mississippi State University, Mississippi State, MS 39762

${ }^{6}$ Department of Horticulture, University of Kentucky, Lexington, KY 40546

${ }^{7}$ Corresponding author. E-mail:fernan15@msu.edu. zone with guard plants surrounding the border to minimize edge effects.

Plant material and treatments. 'Roemertwo' wintercreeper, 'Green Velvet' boxwood, and 'Dark Knight' bluebeard were used for experimental years 2011, 2012, and 2013, respectively. Growing season start dates, end dates, and fertilizer information for each experimental site are shown in Table 1. Plants were potted up on the first day of the experiment. At the end of each growing season, for each container type, 12 plants were randomly selected and destructively harvested. The stems and leaves were separated, and roots were washed with water until no visible substrate particles were attached. Plants were oven dried and then the dry weight was recorded. In Michigan, Kentucky, and Mississippi, remaining plants were kept in the hoop house covered with plastic film over the winter with no irrigation applied during winter to follow common Michigan nursery practice. In Tennessee and Texas, plants were kept in the hoop house covered with plastic film and irrigated as needed during winter. Mortality was recorded in May of the following year for all states. $85 \%$ pine bark:15\% sphagnum peat (vol:vol) (Renewed Earth, Otsego, MI). Over $83 \%, 63 \%, 52 \%$, and $23 \%$
Container substrate consisted of

of the substrate particles passed through a 9.5-, 6.4-, 4.8-, and 2.4-mm screens, respectively, with only $7 \%$ passing through a $\mathrm{l}-\mathrm{mm}$ screen. Container treatments in 2011 were: 1) plastic, 2) WP, and 3) KF. Container treatments in 2012 were 1) plastic, 2) $\mathrm{WP}, 3) \mathrm{FB}$, and 4) KT. Container treatments in 2013 were 1 ) plastic, 2) WP, and 3) Coir. A detailed description of the containers is provided in Table 2.

IRRIGATION APPLICATION AND DAILY WATER USE Overhead irrigation with $100 \%$ head-to-head overlap was used for all locations except Texas. The average irrigation rate for Michigan, Kentucky, Tennessee, and Mississippi were $27.9,42.0,53.9$, and $44.8 \mathrm{~mL} \cdot \mathrm{min}^{-1}$, respectively. Irrigation uniformity for Michigan, Kentucky, Tennessee and Mississippi were $82.0 \%$, $85.8 \%, 71.0 \%$, and $83.7 \%$, respectively.

In Michigan, Kentucky, and Mississippi, two substrate moisture sensors (model EC5; Decagon Devices, Pullman, WA) were inserted at $45^{\circ}$ angles into the center of two containers for each irrigation zone to measure volumetric substrate moisture content $(\theta)$. The sensors were calibrated by correlating readings with container weight change during a substrate dry down cycle. Sensor readings were recorded by a data logger (model CRI000;

Table 1. Growing season start date, end date, fertilizer type, and rate of alternative containers study at Michigan, Kentucky, Tennessee, Mississippi, and Texas from 2011 to 2013.

\begin{tabular}{|c|c|c|c|c|}
\hline State & Start date & End date & Fertilizer type & $\begin{array}{l}\text { Fertilizer rate } \\
(\mathrm{g} / \text { container })^{\mathrm{z}}\end{array}$ \\
\hline \multicolumn{5}{|c|}{2011 Season } \\
\hline Michigan & 16 June 2011 & 26 Oct. 2011 & $17.0 \mathrm{~N}-3.5 \mathrm{P}-6.6 \mathrm{~K}^{\mathrm{y}}$ & 8 \\
\hline Kentucky & 15 May 2011 & 1 Oct. 2011 & $19.0 \mathrm{~N}-2.2 \mathrm{P}-7.5 \mathrm{~K}^{\mathrm{y}}$ & 8 \\
\hline Mississippi & 25 May 2011 & 31 Oct. 2011 & $17.0 \mathrm{~N}-3.5 \mathrm{P}-6.6 \mathrm{~K}^{\mathrm{y}}$ & 8 \\
\hline Texas & 10 June 2011 & 18 Oct. 2011 & $15.0 \mathrm{~N}-9.0 \mathrm{P}-12.0 \mathrm{~K}^{\mathrm{x}}$ & 8 \\
\hline \multicolumn{5}{|c|}{2012 Season } \\
\hline Michigan & 23 June 2012 & 28 Oct. 2012 & $17.0 \mathrm{~N}-3.5 \mathrm{P}-6.6 \mathrm{~K}$ & 8 \\
\hline Kentucky & 1 May 2012 & 2 Oct. 2012 & $19.0 \mathrm{~N}-2.2 \mathrm{P}-7.5 \mathrm{~K}$ & 8 \\
\hline Mississippi & 11 May 2012 & 30 Oct. 2012 & $17.0 \mathrm{~N}-3.5 \mathrm{P}-6.6 \mathrm{~K}$ & 8 \\
\hline Texas & 14 June 2012 & 30 Oct. 2012 & $15.0 \mathrm{~N}-9.0 \mathrm{P}-12.0 \mathrm{~K}$ & 5 \\
\hline \multicolumn{5}{|c|}{2013 Season } \\
\hline Michigan & 1 June 2013 & 17 Oct. 2013 & $17.0 \mathrm{~N}-3.5 \mathrm{P}-6.6 \mathrm{~K}$ & 8 \\
\hline Kentucky & 18 May 2013 & 12 Oct.2012 & $19.0 \mathrm{~N}-2.2 \mathrm{P}-7.5 \mathrm{~K}$ & 8 \\
\hline Tennessee & 3 June 2013 & 24 Oct. 2012 & $19.0 \mathrm{~N}-4.0 \mathrm{P}-8.0 \mathrm{~K}^{\mathrm{w}}$ & 12 \\
\hline Mississippi & 10 May 2013 & 30 Oct. 2013 & $17.0 \mathrm{~N}-3.5 \mathrm{P}-6.6 \mathrm{~K}$ & 8 \\
\hline Texas & 31 May 2013 & 16 Oct. 2013 & $15.0 \mathrm{~N}-9.0 \mathrm{P}-12.0 \mathrm{~K}$ & 5 \\
\hline
\end{tabular}

${ }^{\mathrm{z}} 1 \mathrm{~g}=0.0353 \mathrm{oz}$

'Release period of 3 to 4 mo. fertilizer (Harrell's, Lakeland, FL).

${ }^{x}$ Release period of 5 to 6 mo. (Osmocote CRF; Scotts, Marysville, OH).

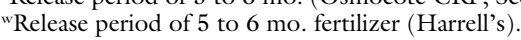


Table 2. Container type, abbreviation, product name, constructed material, volume (gal), and manufacturer of containers used in 2011,2012 , and 2013 alternative container studies.

\begin{tabular}{|c|c|c|c|c|c|}
\hline $\begin{array}{l}\text { Container } \\
\text { type }\end{array}$ & Abbreviation & $\begin{array}{c}\text { Product } \\
\text { name }^{\mathrm{z}}\end{array}$ & $\begin{array}{c}\text { Constructed } \\
\text { material }\end{array}$ & $\begin{array}{l}\text { Volume } \\
(\text { gal })^{\mathrm{z}}\end{array}$ & Manufacturer \\
\hline Black plastic & Plastic & PS 400-SM & Polyethylene & 1 & $\begin{array}{l}\text { Nursery Supplies, } \\
\text { Chambersburg, PA }\end{array}$ \\
\hline Wood pulp & WP & 7X7 RD & $\begin{array}{l}\text { Molded recycled } \\
\text { paper }\end{array}$ & 1 & $\begin{array}{l}\text { Western Pulp Products, } \\
\text { Corvallis, OR }\end{array}$ \\
\hline $\begin{array}{l}\text { Recycled } \\
\text { paper }\end{array}$ & $\mathrm{KF}$ & $\begin{array}{l}\text { Kord 07.50 Fiber } \\
\text { Grow Pot }\end{array}$ & Recycled paper & 1 & $\begin{array}{l}\text { ITML Horticultural } \\
\text { Products, Middlefield, } \mathrm{OH}\end{array}$ \\
\hline Keratin & KT & Keratin container & $\begin{array}{l}\text { Recycled plastic with } \\
\text { poultry feather }\end{array}$ & 0.8 & $\begin{array}{l}\text { Horticultural Research } \\
\text { Institute, Washington, DC }\end{array}$ \\
\hline Coir fiber & Coir & $\begin{array}{l}\text { QuickStart 8" } \\
\text { Retail } \\
\text { Nursery Pot }\end{array}$ & Coconut fiber & 1 & $\begin{array}{l}\text { PlantBest, Markham, } \\
\text { ON, Canada }\end{array}$ \\
\hline
\end{tabular}

${ }^{\mathrm{z}} 1$ inch $=2.54 \mathrm{~cm}, 1 \mathrm{gal}=3.7854 \mathrm{~L}$.

Campbell Scientific, Logan, UT) every $15 \mathrm{~min}$. The data logger was programmed using CRBasic Language with support software (LoggerNet, Campbell Scientific). In this experiment, WU was calculated by the equation: $\mathrm{WU}=\left(\theta_{\mathrm{AI}}-\theta_{\mathrm{BI}}\right) \times$ container volume. $\theta_{\mathrm{AI}}$ was $\theta$ measured 5 min after irrigation application and $\theta_{\mathrm{BI}}$ was $\theta$ measured right before the next irrigation event. The substrate used in this study resulted in gravitational water drainage from the sensor zone after $5 \mathrm{~min}$. The data logger was programmed to calculate irrigation time using the average WU divided by application rate in each irrigation zone and then trigger the solenoid to irrigate. Irrigation was split into two applications per day initiated at 0700 and 1900 HR. For each experimental day, daily water use (DWU) was the sum of the two WU measurements taken at 0700 and $1900 \mathrm{HR}$. On the first day of experiment every year, the containers were irrigated to saturation, after given adequate time for the containers to drain, the data logger program was set to take the first measurement of $\theta$ as $\theta_{\mathrm{AI}}$ initial value.

For the Tennessee site, the irrigation method was the same as described above except that the plants were watered only once per day at $0800 \mathrm{HR}$. At the Texas site, the plants were watered the same as described above in 2011; in 2012 and 2013, the plants were hand watered twice daily at 0700 and $1300 \mathrm{HR}(\approx 500 \mathrm{~mL})$. The DWU was determined by weighing the containers at $0830 \mathrm{HR}$, which is $1.5 \mathrm{~h}$ after irrigation and again at

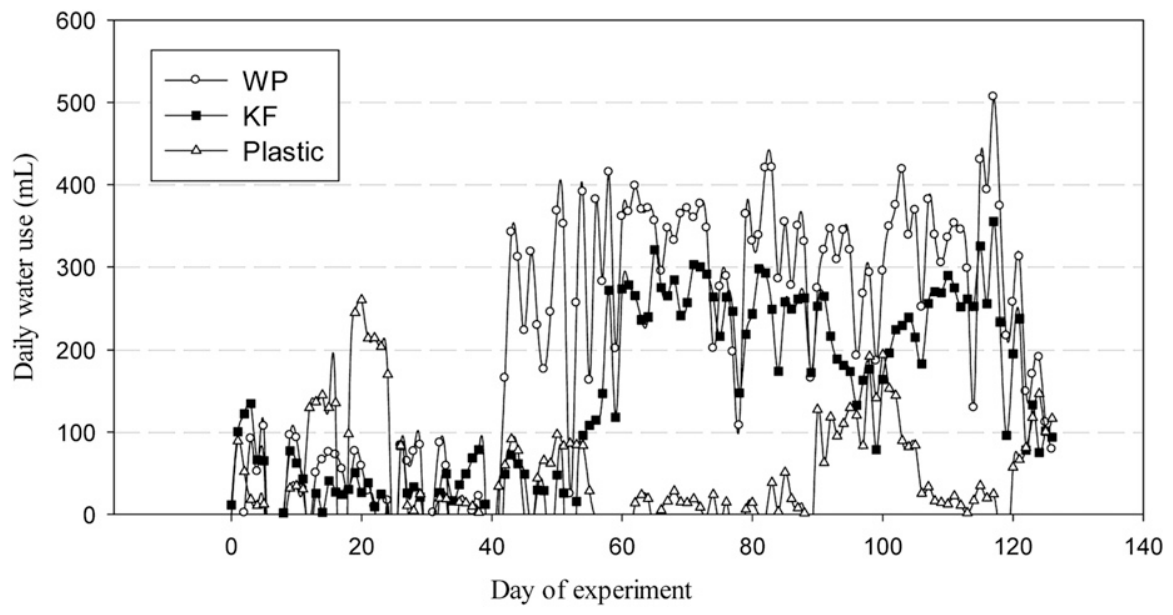

Fig. 1. Daily water use of 'Roemertwo' wintercreeper grown in WP (alternative container made from recycled paper by Western Pulp Products, Corvallis, OR), KF (alternative containers made from recycled paper by ITML Horticultural Products, Middlefield, $\mathrm{OH}$ ) and plastic containers from 16 June 2011 (Day 0) to 26 Oct. 2011 at Michigan; $1 \mathrm{~mL}=0.0338 \mathrm{fl} \mathrm{oz}$.

0830 HR on the next day and irrigation was withheld for $24 \mathrm{~h}$ on days when container weights were taken.

Plant growth Index and WU EFFICIENCY. Plant growth index (GI) was measured about every 2 weeks. Growth index was calculated as GI = (height + width $1+$ width 2$) / 3$, where the plant height was taken from the rim of the container to the highest point of the plant, width 1 was the width of the plant in the north to south direction and width 2 was the width of the plant in the west to east direction using fixed pot labels to maintain orientation.

To further investigate plant response to irrigation volume, water use efficiency (WUE) was calculated as plant biomass divided by cumulative DWU. Because of a disease issue, Mississippi, Texas, and Kentucky locations had high mortality of plants in 2011 , so only data in 2011 from Michigan is presented. Tennessee joined the experiment in 2013.

LEACHATE ELECTRICAL CONDUCTIVITY AND $\mathbf{P H}$. Electrical conductivity (EC) and $\mathrm{pH}$ were measured about every month using the pour through method described by Yeager (2003). A plastic tray was placed under the container $30 \mathrm{~min}$ after irrigation was applied, then $200 \mathrm{~mL}$ reverse osmosis water was added to the container, a bulb syringe was used to extract leachate from the tray and release it onto the sensor of a Cardy 
Twin EC Meter and Cardy Twin $\mathrm{pH}$ Meter (Horiba, Kyoto, Japan). This measurement was only carried out in Michigan from 2011 to 2013; therefore, only data from Michigan was presented.

Statistical analysis. Growth index, EC and $\mathrm{pH}$ were analyzed as repeated measurements using PROC MIXED procedure of SAS (version 9.2; SAS Institute, Cary, NC). When significant at the 0.05 level, treatment means on each measurement day were separated using a $t$ test in the PDIFF option of the LSMEANS statement and the SLICE option of PROC $\operatorname{MIXED}(\alpha=0.05)$. Daily water use and WUE were analyzed using PROC GLM procedure of SAS and, when significant, means were separated using Tukey's test at 0.05 significance level.

\section{Results and discussion Daily water use}

2011 (ONLY DATA FROM Michigan are presented). The DWU of plants in WP and KF containers was similar to that of plastic containers in the beginning of the season but generally higher than that of plastic containers after day 50 (Fig. 1). The seasonal daily average DWU of wintercreeper grown in WP, $\mathrm{KF}$, and plastic containers was 225.6, 144.0 , and $60.0 \mathrm{~mL}$, respectively. The average DWU of plants grown in WP containers was the largest vs. that in plastic containers was the lowest. Frequent rainfall occurred from day 60 through most of the fall contributing to the low WU for plastic containers, while fiber containers were degrading over the season and likely had greater water permeability as the season progressed. The maximum air temperature was typically between 23 and $28^{\circ} \mathrm{C}$ in that period and could also contribute to the low WU of plastic containers.

2012. The average seasonal plant DWU in plastic and alternative containers varied by state (Fig. 2). Within all states, plant DWU in KT containers was the lowest compared with that of other containers. This was because KT containers had container walls that were nearly impervious and a smaller container volume. Plants in WP containers had the highest WU in Mississippi and Texas. In Kentucky, plants in FB containers had highest DWU, while plants in plastic

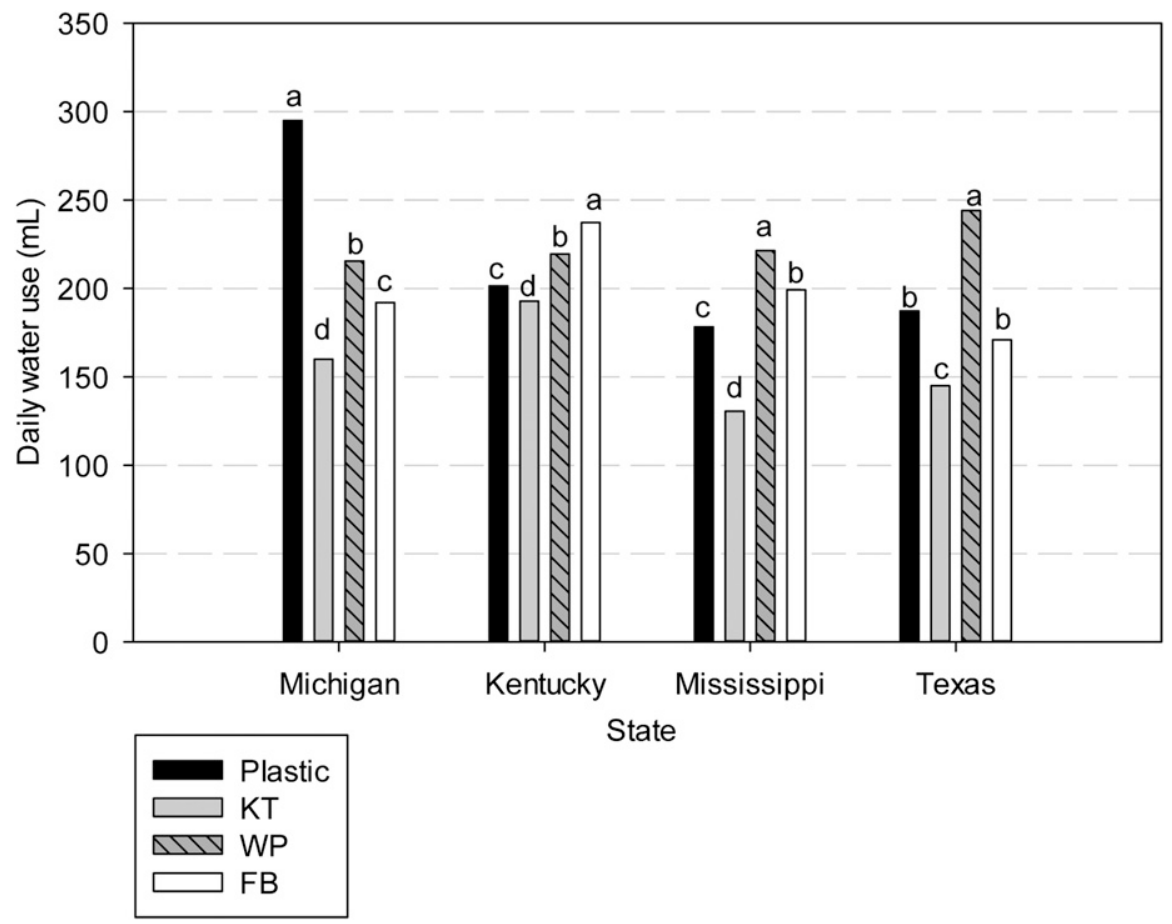

Fig. 2. Seasonal average daily water use in 2012 of 'Green Velvet' boxwood grown in WP (alternative container made from recycled paper by Western Pulp Products, Corvallis, OR), KT (alternative container made from keratin by Horticultural Research Institute. Washington, DC), plastic, and FB (alternative container made from a mixture of recycled plastic fiber and natural material by Central Bag $\&$ Burlap, Denver, CO) containers at Michigan, Kentucky, Mississippi, and Texas. Bars with the same letter are not significantly different according to Tukey's significance test $(\alpha=0.05) ; 1 \mathrm{~mL}=0.0338 \mathrm{fl} \mathrm{oz}$.

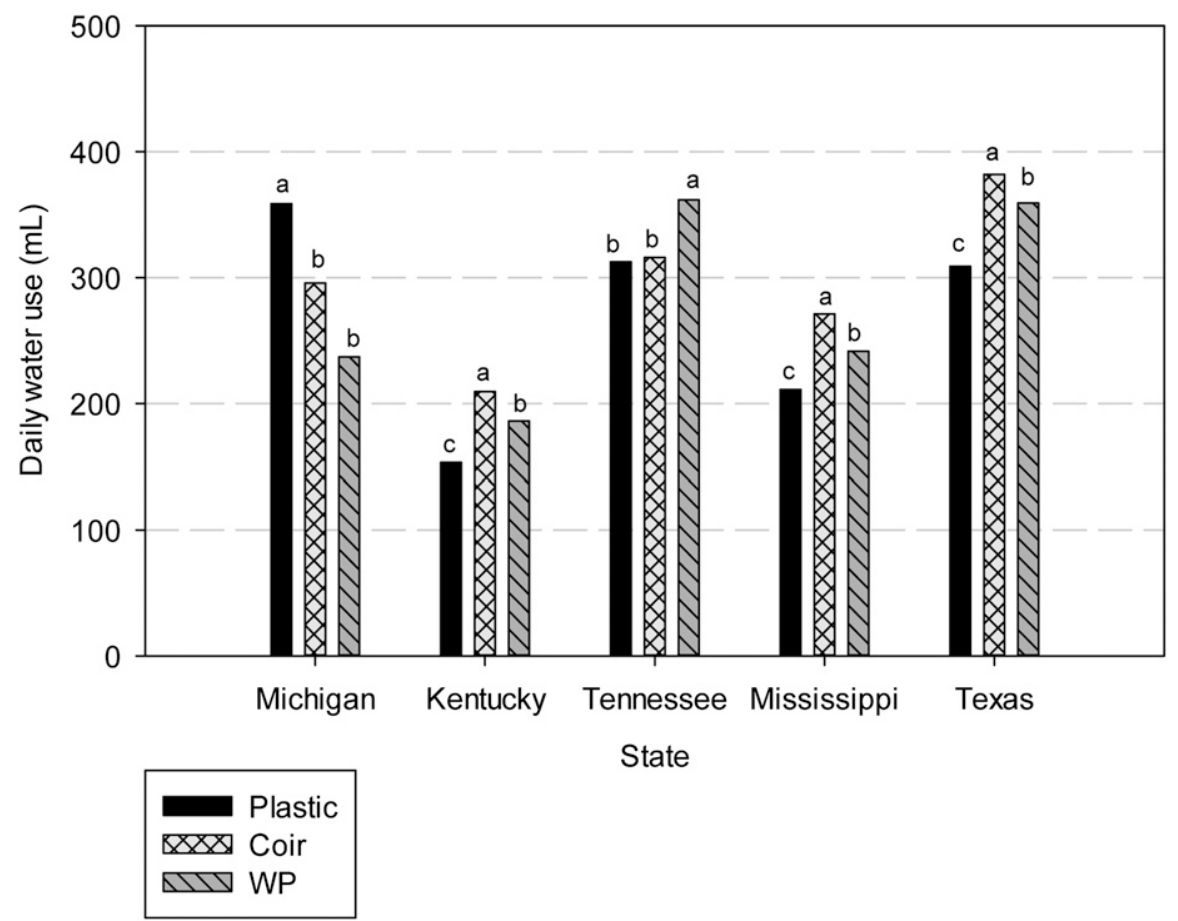

Fig. 3. Seasonal average daily water use in 2013 of 'Dark Knight' bluebeard grown in WP (alternative container made from recycled paper by Western Pulp Products, Corvallis, OR), Coir (alternative container made from coir fiber by PlantBest, Markham, ON, Canada), and plastic containers at Michigan, Kentucky, Tennessee, Mississippi, and Texas. Bars with the same letter are not significantly different according to Tukey's significance test $(\alpha=0.05) ; 1 \mathrm{~mL}=0.0338 \mathrm{fl} \mathrm{oz}$. 
containers had the highest DWU in Michigan.

2013. The difference between seasonal average plant DWU in alternative containers and plastic containers was similar in Mississippi, Texas, and Kentucky (Fig. 3). In Mississippi, Texas, and Kentucky, plants in Coir containers had the greatest DWU, while plants in plastic containers had the lowest. In Michigan, DWU of plants grown in plastic containers was greater than that of WP and Coir containers. Conversely, in Tennessee, DWU of plants grown in WP containers was greater than that of plastic and Coir containers.

Evans and Hensley (2004) found that the rate of water loss through the container wall was a major factor affecting WU. The differences of plant DWU in alternative and plastic containers in this study were generally supported by the relative side wall porosity found in each container under controlled environmental conditions (Nambuthiri et al., 2015b), where water loss was greatest in FB and Coir containers, intermediate in $\mathrm{WP}$, and least in plastic and KT containers. Supraoptimal root temperatures in plastic containers for all states except Michigan (Nambuthiri et al., 2015b) may have resulted in the higher DWU in plastic for Michigan than for other states.

\section{Plant growth and dry weight}

2011 (ONLY DATA FROM MiChigAn ARE PRESENTED). The final GI of wintercreeper in 2011 was $18.8 \mathrm{~cm}$ with no difference between treatments. There were no differences in dry leaf, shoot, and root weights between treatments (Table 3 ). The mortality rate of plants grown in WP, KF and plastic was $2 \%, 2 \%$, and $13 \%$ on 11 Oct. 2011 and increased to $52 \%, 52 \%$, and $15 \%$ on 6 June 2012, respectively. Since there was no irrigation supply in the Michigan hoop houses during winter, the higher mortality rate of plants grown in WP and KF containers over the winter could be attributed to faster desiccation of substrate in fiber containers than plastic containers.

2012. The average final GI of boxwood in Mississippi, Kentucky, and Michigan was 20.4, 20.0, and $16.7 \mathrm{~cm}$, respectively, with no difference between treatments. In Texas, where plants were watered $\approx 500 \mathrm{~mL}$ daily regardless of container types, the final GI of plants grown in KT, plastic, FB, and WP containers was $15.9,14.9,12.4$, and $14.1 \mathrm{~cm}$, respectively. Plants grown in KT containers had the greatest growth while

those in FB containers had the least growth. Plants grown in plastic and WP containers had intermediate growth. The mortality for boxwood was zero for all states.

Table 3. Dry leaf, stem, root, and total weight of 'Roemertwo' wintercreeper grown from 16 June 2011 to 26 Oct. 2011 in three container types at Michigan.

\begin{tabular}{lcccr}
\hline $\begin{array}{l}\text { Container } \\
\text { type }^{\mathbf{z}}\end{array}$ & $\begin{array}{c}\text { Leaves } \\
\mathbf{w t}(\mathbf{g})^{\mathbf{y}}\end{array}$ & $\begin{array}{c}\text { Stem } \\
\mathbf{w t}(\mathbf{g})\end{array}$ & $\begin{array}{c}\text { Root } \\
\mathbf{w t}(\mathbf{g})\end{array}$ & $\begin{array}{r}\text { Total } \\
\mathbf{w t}(\mathbf{g})\end{array}$ \\
\hline Plastic & 1.4 & 3.0 & 4.2 & 8.6 \\
$\mathrm{WP}^{\mathrm{y}}$ & 2.8 & 4.2 & 7.0 & 14.0 \\
$\mathrm{KF}^{\mathrm{x}}$ & 2.7 & 3.3 & 5.3 & 11.3 \\
& $\mathrm{NS}^{\mathrm{x}}$ & $\mathrm{NS}$ & $\mathrm{NS}$ & $\mathrm{NS}$ \\
\hline
\end{tabular}

${ }^{2} \mathrm{WP}=$ alternative containers made from recycled paper (Western Pulp Products, Corvallis, OR), KF = alternative containers made from recycled paper (ITML Horticultural Products, Middlefield, OH)

${ }^{\mathrm{y}} \mathrm{lg}=0.0353 \mathrm{oz}$.

${ }^{x}$ Means with Ns in the same column are not different. Means separated by Tukey's significance test $(\alpha=0.05)$.

Table 4. Shoot and root dry weight of 'Green Velvet' boxwood grown in four container types at Michigan, Kentucky, Mississippi, and Texas.

\begin{tabular}{|c|c|c|c|c|}
\hline \multirow[b]{2}{*}{ Container types ${ }^{\mathrm{z}}$} & Michigan $^{\mathrm{y}}$ & Kentucky $^{\mathrm{y}}$ & Mississippi $\mathbf{i}^{\mathrm{y}}$ & Texas $^{y}$ \\
\hline & \multicolumn{4}{|c|}{ Shoot dry wt $(g)^{x}$} \\
\hline Plastic & 14.2 & $11.9 \mathrm{a}^{\mathrm{w}}$ & 14.0 & $11.8 \mathrm{a}$ \\
\hline $\mathrm{KT}$ & 15.7 & $12.0 \mathrm{a}$ & 12.3 & $11.5 \mathrm{a}$ \\
\hline WP & 15.5 & $10.3 \mathrm{~b}$ & 13.8 & $8.7 \mathrm{~b}$ \\
\hline \multirow[t]{3}{*}{$\mathrm{FB}$} & 14.3 & $10.5 \mathrm{~b}$ & 14.0 & $8.6 \mathrm{~b}$ \\
\hline & $\mathrm{NS}^{\mathrm{v}}$ & & NS & \\
\hline & \multicolumn{4}{|c|}{ Root dry wt (g) } \\
\hline Plastic & $9.9 \mathrm{a}$ & $9.5 \mathrm{~b}$ & $10.6 \mathrm{a}$ & $8.7 \mathrm{a}$ \\
\hline $\mathrm{KT}$ & $8.3 \mathrm{a}$ & $10.0 \mathrm{a}$ & $7.8 \mathrm{~b}$ & $6.6 \mathrm{~b}$ \\
\hline WP & $9.2 \mathrm{a}$ & $9.9 \mathrm{a}$ & $10.5 \mathrm{a}$ & $7.1 \mathrm{ab}$ \\
\hline $\mathrm{FB}$ & $8.9 \mathrm{a}$ & $8.5 \mathrm{c}$ & $8.0 \mathrm{a}$ & $6.3 \mathrm{~b}$ \\
\hline
\end{tabular}

${ }^{2} \mathrm{KT}=$ alternative container made from keratin (Horticultural Research Institute, Washington, DC), WP $=$ alternative container made from recycled paper (Western Pulp Products, Corvallis, OR), FB = alternative container made from a mixture of recycled plastic fiber and natural material (Central Bag \& Burlap, Denver, CO).

yPlants were grown in Michigan from 23 June 2012 to 28 Oct. 2012, from 1 May 2012 to 2 Oct. 2012 in Kentucky, from 11 May 2012 to 30 Oct. 2012 in Mississippi, and from 14 June 2012 to 30 Oct. 2012 in Texas. ${ }^{x} 1 \mathrm{~g}=0.0353 \mathrm{oz}$.

"Means with the same letter in the same column are not different. Means separated by Tukey's significance test $(\alpha=0.05)$. "Means with Ns in the same column are not different. Means separated by Tukey's significance test $(\alpha=0.05)$.

Table 5. Shoot and root dry weight of 'Dark Knight' bluebeard grown in three container types at Michigan, Kentucky, Tennessee, Mississippi, and Texas.

\begin{tabular}{|c|c|c|c|c|c|}
\hline \multirow[b]{2}{*}{ Container types } & Michigan $^{\mathrm{y}}$ & Kentucky $^{\mathrm{y}}$ & Tennessee $^{\mathrm{y}}$ & Mississippi $\mathbf{i}^{\mathrm{y}}$ & Texas $^{\mathrm{y}}$ \\
\hline & \multicolumn{5}{|c|}{ Shoot dry wt $(g)^{x}$} \\
\hline Plastic & 21.9 & 32.1 & $56.0 \mathrm{a}^{\mathrm{w}}$ & 41.6 & 8.8 \\
\hline Coir & 20.8 & 28.2 & $55.1 \mathrm{a}$ & 38.5 & 7.6 \\
\hline \multirow[t]{3}{*}{ WP } & 20.6 & 34.8 & $45.3 \mathrm{~b}$ & 37.3 & 8.1 \\
\hline & $\mathrm{Ns}^{\mathrm{v}}$ & NS & & NS & NS \\
\hline & \multicolumn{5}{|c|}{ Root dry wt (g) } \\
\hline Plastic & $23.7 \mathrm{a}$ & $26.8 \mathrm{a}$ & 26.4 & 24.1 & $11.7 \mathrm{a}$ \\
\hline Coir & $16.9 \mathrm{~b}$ & $14.8 \mathrm{~b}$ & 24.9 & 23.2 & $12.3 \mathrm{a}$ \\
\hline \multirow[t]{2}{*}{ WP } & $20.3 \mathrm{ab}$ & $24.4 \mathrm{a}$ & 26.0 & 23.9 & $8.5 \mathrm{~b}$ \\
\hline & & & NS & NS & \\
\hline
\end{tabular}

${ }^{\mathrm{z}}$ Coir = alternative container made from coir fiber (PlantBest, Markham, ON, Canada), WP = alternative container made from recycled paper (Western Pulp Products, Corvallis, OR).

${ }^{y}$ Plants were grown from 1 June 2013 to 17 Oct. 2013 in Michigan, from 18 May 2013 to 12 Oct. 2013 in Kentucky, from 3 June 2013 to 24 Oct. 2013 in Tennessee, from 10 May 2013 to 30 Oct. 2013 in Mississippi and from 31 May 2013 to 16 Oct. 2013 in Texas.

${ }^{\mathrm{x}} \mathrm{lg}=0.0353 \mathrm{oz}$

${ }^{w}$ Means with the same letter in the same column are not different. Means separated by Tukey's significance test $(\alpha=0.05)$.

${ }^{\vee}$ Means with Ns in the same column are not different. Means separated by Tukey's significance test $(\alpha=0.05)$. 
Table 6. Water use efficiency of 'Roemertwo' wintercreeper, 'Green Velvet' boxwood, and 'Dark Knight' bluebeard grown in six container types at Michigan, Kentucky, Mississippi, and Texas.

\begin{tabular}{lccccc}
\hline & \multicolumn{5}{c}{ Water use efficiency $\left(\mathrm{g} \cdot \mathbf{L}^{-1}\right)^{\mathrm{z}}$} \\
\hline $\begin{array}{l}\text { 2011 'Roemertwo' } \\
\text { wintercreeper }\end{array}$ & Michigan & & & & \\
Plastic & $1.1 \mathrm{a}^{\mathrm{y}}$ & & & & \\
WP $^{\mathrm{x}}$ & $0.6 \mathrm{a}$ & & & & \\
KF $^{\mathrm{x}}$ & $0.5 \mathrm{a}$ & & & & \\
2012 'Green Velvet' boxwood & Michigan & Kentucky & Mississippi & Texas & \\
Plastic & $0.7 \mathrm{~b}$ & $0.7 \mathrm{a}$ & $0.8 \mathrm{a}$ & $0.8 \mathrm{a}$ & \\
KT $^{\mathrm{x}}$ & $1.2 \mathrm{a}$ & $0.7 \mathrm{a}$ & $0.9 \mathrm{a}$ & $0.9 \mathrm{a}$ & \\
WP & $0.8 \mathrm{~b}$ & $0.7 \mathrm{a}$ & $0.6 \mathrm{~b}$ & $0.5 \mathrm{c}$ & \\
FB $^{\mathrm{x}}$ & $0.9 \mathrm{ab}$ & $0.5 \mathrm{~b}$ & $0.6 \mathrm{~b}$ & $0.6 \mathrm{~b}$ & \\
2013 'Dark Knight' bluebeard & Michigan & Kentucky & Tennessee & Mississippi & Texas \\
Plastic & $0.9 \mathrm{~b}$ & $2.6 \mathrm{a}$ & $1.8 \mathrm{a}$ & $1.8 \mathrm{a}$ & $0.5 \mathrm{a}$ \\
Coir & $0.9 \mathrm{~b}$ & $1.4 \mathrm{~b}$ & $1.8 \mathrm{a}$ & $1.3 \mathrm{~b}$ & $0.4 \mathrm{~b}$ \\
WP & $1.3 \mathrm{a}$ & $2.2 \mathrm{a}$ & $1.4 \mathrm{~b}$ & $1.5 \mathrm{~b}$ & $0.3 \mathrm{~b}$ \\
\hline
\end{tabular}

${ }^{\mathrm{z}} 1 \mathrm{~g} \cdot \mathrm{L}^{-1}=0.1 \%$.

${ }^{y}$ Means with the same letter in the same column are not different. Means separated by Tukey's significance test $(\alpha=$ 0.05 ).

${ }^{\mathrm{x}} \mathrm{WP}=$ alternative container made from recycled paper (Western Pulp Products, Corvallis, OR), KF $=$ alternative containers made from recycled paper (ITML Horticultural Products, Middlefield, OH), KT = alternative container made from keratin (Horticultural Research Institute, Washington, DC), FB = alternative container made from a mixture of recycled plastic fiber and natural material (Central Bag \& Burlap, Denver, CO), Coir = alternative container made from coir fiber (PlantBest, Markham, ON, Canada).
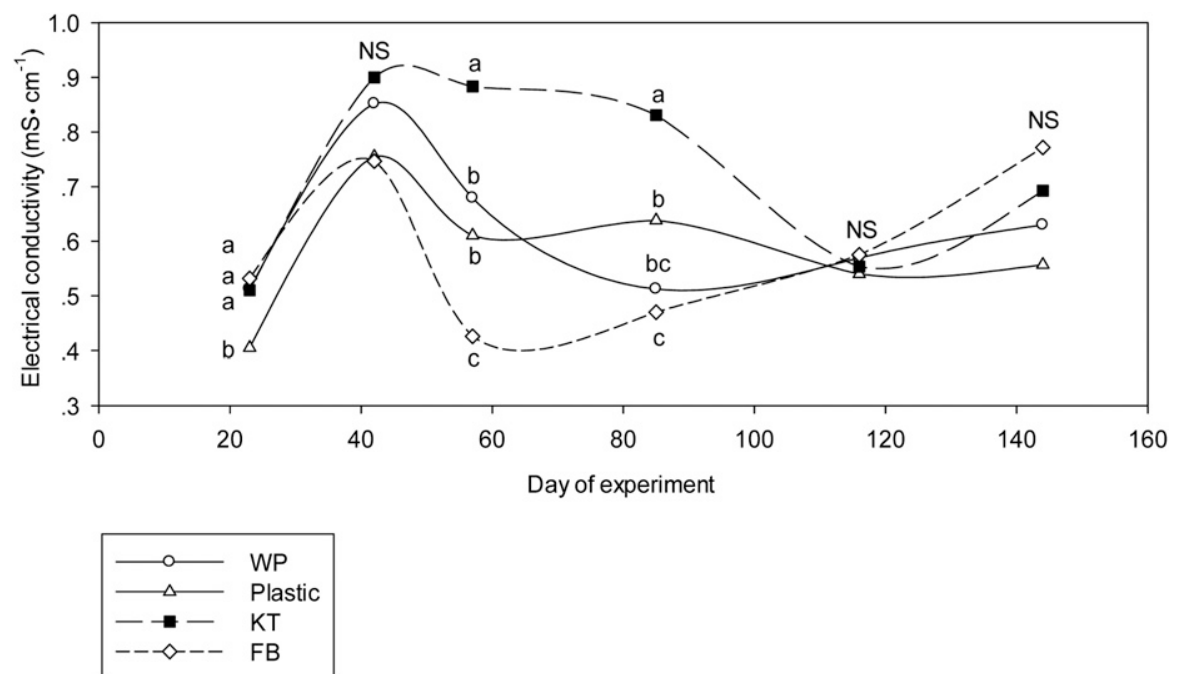

Fig. 4. Leachate EC of 'Green Velvet' Boxwood grown in WP (alternative container made from recycled paper by Western Pulp Products, Corvallis, OR), plastic, KT (alternative container made from keratin by Horticultural Research Institute. Washington, DC), and FB (alternative container made from a mixture of recycled plastic fiber and natural material by Central Bag \& Burlap, Denver, CO) containers on experimental days $23,42,57,85,116$, and 114 (day $0=14$ May 2012). Means with the same letter within the same date are not significantly different according to Tukey's significance test $(\alpha=0.05)$; NS indicates no difference in electrical conductivity between container types within the same date; $1 \mathrm{mS} \cdot \mathrm{cm}^{-1}=1 \mathrm{mmhos} / \mathrm{cm}$.

The shoot and root dry weight of boxwood grown in KT, plastic, FB, and WP containers varied by states (Table 4). In Michigan, there were no differences in dry weight due to treatments. In Mississippi, there were no weight than WP and FB and higher root dry weight in plastic than $\mathrm{KT}$ and FB. In Kentucky, plants grown in plastic and KT containers had a higher shoot dry weight vs. WP and FB containers and higher root dry weight in KT and WP than plastic and FB. Evans and Hensley (2004) reported that when irrigation was applied as needed, plants grown in poultry feather containers had a greater growth than those in plastic containers. The poultry feather containers used in their experiment consisted of $15 \%$ craft paper and $85 \%$ processed feather fiber, which provided an available nitrogen resource to the plants. However, there was no indication that the poultry feather component in KT containers contributed to plant growth in the current experiment.

2013. The final GI of bluebeard grown in plastic, Coir, and WP containers in Michigan, Kentucky, Mississippi, and Tennessee was 35.0, $40.4,40.0$, and $58.3 \mathrm{~cm}$, respectively, with no difference between treatments. In Texas, plants grown in plastic and Coir containers had greater GI compared with that in WP containers. For dry shoot weight, there was no difference between treatments in Michigan, Mississippi, Texas, and Kentucky (Table 5). In Tennessee, plants grown in plastic and Coir containers had a greater dry weight than that of WP containers. For dry root weight, there was no difference between treatments in Mississippi and Tennessee. In Michigan and Kentucky, plants grown in plastic containers had greater growth than that of WP containers. In Texas, plants grown in plastic and WP containers had greater growth compared with that of Coir containers. There was no mortality of bluebeard in any state in Nov. 2013. In May 2014, the mortality of bluebeard remained zero for Tennessee and Mississippi. In Texas, the mortality of bluebeard in plastic containers increased to $4 \%$. Michigan and Kentucky lost the majority of the plants due to winter kill regardless of treatment.

When combining 3 years data at five experimental locations, plants grown in alternative containers generally had similar growth compared with that of plastic containers. The high mortality of wintercreeper grown in WP and KF containers over the winter in Michigan in 2011 

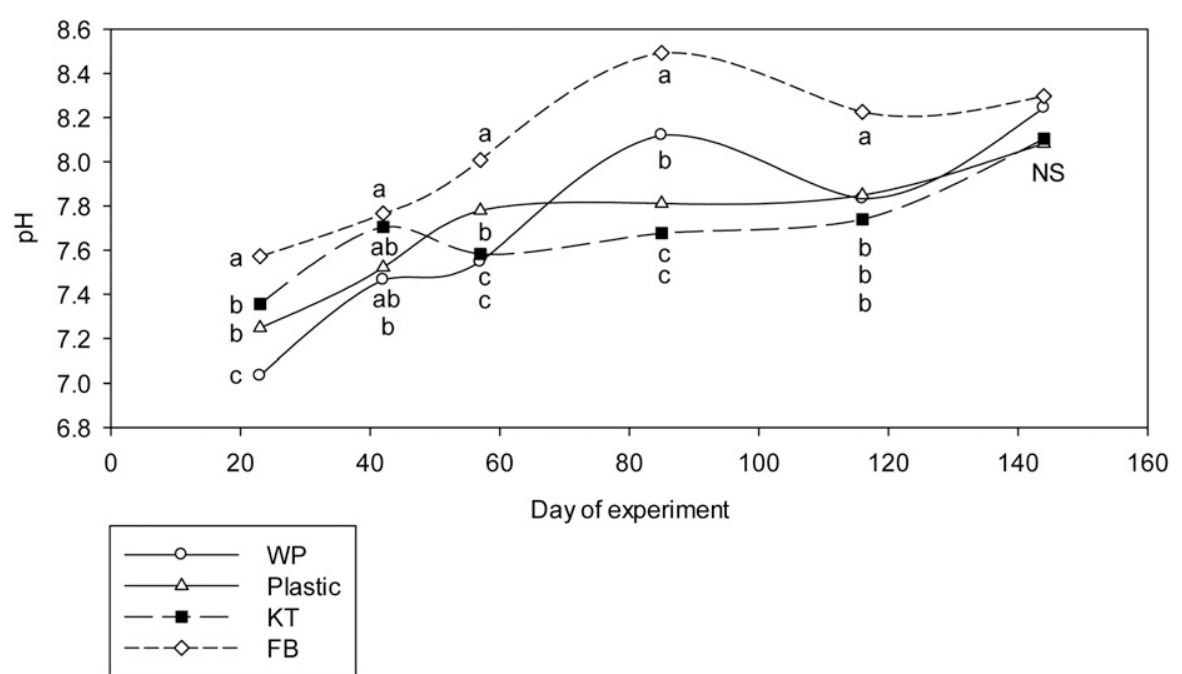

Fig. 5. Leachate pH of 'Green Velvet' Boxwood grown in WP (alternative container made from recycled paper by Western Pulp Products, Corvallis, OR), plastic, KT (alternative container made from keratin by Horticultural Research Institute. Washington, DC), and FB (alternative container made from a mixture of recycled plastic fiber and natural material by Central Bag \& Burlap, Denver, CO) containers on experimental days $23,42,57,85,116$, and 114 (day $0=14$ May 2012). Means with the same letter within the same date are not different. Means separated by Tukey's significance test $(\alpha=0.05)$; NS indicates no difference in $\mathrm{pH}$ between container types within the same date.

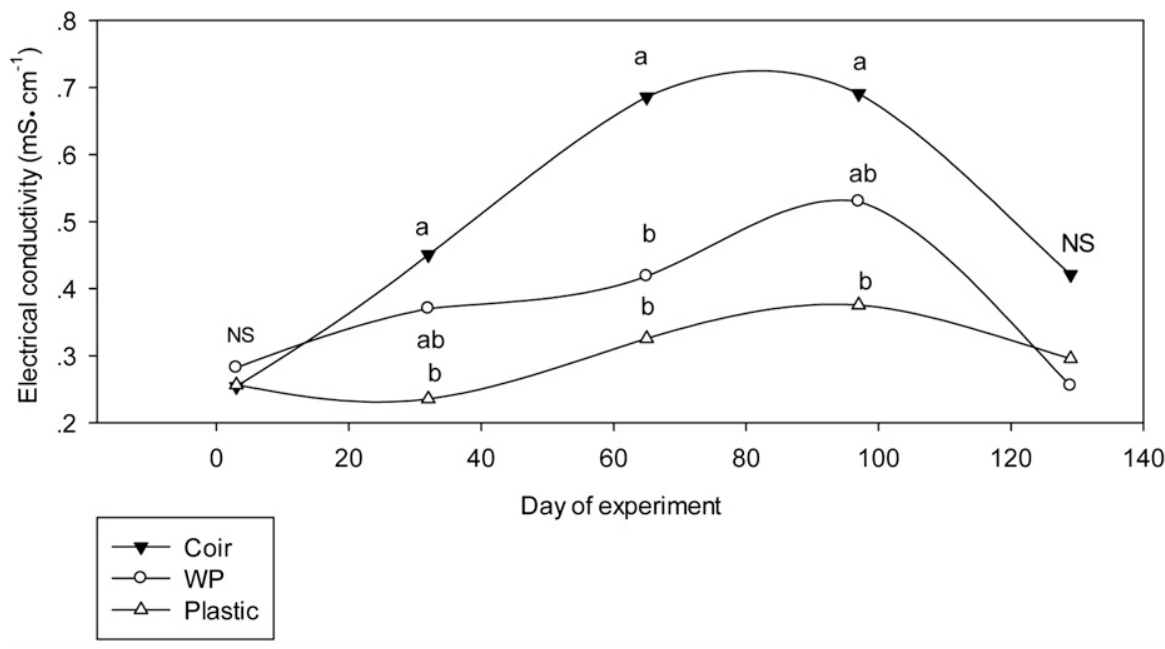

Fig. 6. Leachate electrical conductivity of 'Dark Knight' bluebeard grown in Coir (alternative container made from coir fiber by PlantBest, Markham, ON, Canada), WP (alternative container made from recycled paper by Western Pulp Products, Corvallis, OR), and plastic containers on experimental days 3, 32, 65, 97, and 129 (day 0 = 1 June 2013). Means with the same letter within the same date are not different. Means separated by Tukey's significance test $(\alpha=0.05)$. NS suggest no difference in EC between container types within the same date; $1 \mathrm{mS} \cdot \mathrm{cm}^{-1}=1$ $\mathrm{mmho} / \mathrm{cm}$.

indicated that growers should monitor the substrate moisture during winter and irrigate accordingly when using containers with porous side walls.

\section{Water use efficiency}

The WUE of wintercreeper, boxwood and bluebeard plants grown in the WUE of 'Rutgers' tomato grown in paper-fiber containers with two coats of polyurethane was greater than that of uncoated containers. The KT containers used in this study had nearly impervious container side walls similar to plastic containers and also had a smaller container volume. These two factors likely contributed to the high WUE of KT containers. In 2013, all states except Michigan had higher WUE for bluebeard when grown in black plastic containers compared with those in Coir and WP containers.

\section{Leachate $\mathrm{EC}$ and $\mathrm{pH}$ (only data from Michigan are presented)}

In 2011, the seasonal average leachate $\mathrm{EC}$ and $\mathrm{pH}$ were 0.4 $\mathrm{mS} \cdot \mathrm{cm}^{-1}$ and 7.4 with no differences between treatments for any dates measured. In 2012, on days 57 and 85 , the substrate EC in KT containers was greater than in $\mathrm{FB}$ containers (Fig. 4). The substrate EC in WP and plastic containers were generally intermediate. This could be due to more rapid leaching from $\mathrm{FB}$ containers since the FB containers are made from more porous material. In addition, as water evaporated, some of the nutrients could have moved to the container wall. Leachate $\mathrm{pH}$ from FB containers was higher than other containers for most of the season (Fig. 5); however, the final leachate $\mathrm{pH}$ was similar between treatments. In 2013, EC of the pour through leachate from Coir containers was generally higher than that of WP and plastic containers; however, there was no difference on the first and last data collection day (Fig. 6). The average $\mathrm{pH}$ of pour through leachate was 7.9 with no difference between container types for all dates measured.

\section{Conclusions}

In summary, plant growth in all alternative containers was similar to those grown in plastic containers in current experiment when irrigation was applied based on WU. The different overwinter mortality between wintercreeper, boxwood, and bluebeard suggests that growers need to consider substrate moisture availability and plant water stress tolerance when containers with high water loss are used in climates where winter irrigation is not typical. Most states found that alternative containers 
made from fiber material (WP, KF, $\mathrm{FB}$, and Coir container) used more water than that of plastic and $\mathrm{KT}$ containers. The environmental benefit of using alternative containers must be weighed against water usage and cost. Since both water and petroleum are valuable resources with increasing global demand, alternative containers that produce high quality plants with small water usage should be investigated.

\section{Literature cited}

Beeson, R.C., Jr., M.A. Arnold, B.B. Bilderback, S. Chandler, H.M. Gramling, J.D. Lea-Cox, J.R. Harris, P.J. Klinger, H.M. Mathers, J.M. Ruter, and T.H. Yeager. 2004. Strategic vision of container nursery irrigation in the next ten year. J. Environ. Hort. 22:113-115.

Evans, M.R. and D.L. Hensley. 2004. Plant growth in plastic, peat, and processed poultry feather fiber growing containers. HortScience 39:1012-1014.

Hall, C.R., B.L. Campbell, B.K. Behe, C. Yue, R.G. Lopez, and J.H. Dennis. 2010. The appeal of biodegradable packaging to floral consumers. HortScience 45:583-591.

Helgeson, M.S., W.R. Graves, D. Grewell, and G. Srinivasan. 2009. Degradation and nitrogen release of zein-based bioplastic containers. J. Envrion. Hort 27:123127.

Hopewell, J., R. Dvorak, and E. Kosior. 2009. Plastics recycling: Challenges and opportunities. Philosophical Trans. Royal Soc. B Biol. Sci. 364:2115-2126.

Koeser, A., S.T. Lovell, M.R. Evans, and J.R. Stewart. 2013. Biocontainer water use in short-term greenhouse crop production. HortTechnology 23:215-219.

Kuehny, J.S., M. Taylor, and M.R. Evans. 2011. Greenhouse and landscape performance of bedding plants in biocontainers. Hort Technology 21:155-161.

Lopez, R.G. and D.M. Camberato. 2011. Growth and development of 'Eckespoint Classic Red' poinsettia in biodegradable and compostable containers. HortTechnology 21:419-423.

McCabe, K.G., J.A. Schrader, S. Madbouly, D. Grewell, and W.R. Graves. 2014. Evaluation of biopolymer-coated fiber containers for container-grown plants. HortTechnology 24:439-448.

Nambuthiri, S., A. Fulcher, A.K. Koeser, R.L. Geneve, and G. Niu. 2015a. Moving toward sustainability with alternative containers for greenhouse and nursery crop production: A review and research update. HortTechnology 25:8-16.
Nambuthiri, S., R.L. Geneve, Y. Sun, X. Wang, R.T. Fernandez, G. Niu, G. Bi, and A. Fulcher. 2015b. Substrate temperature in plastic and alternative nursery containers. HortTechnology 25:50-56.

Schrader, J.A. 2013. Report on the annual consumption of plastics for specialty-crop containers in the United States. 22 Sept. 2014. <http://www.public.iastate.edu/ bioplastic/Images\%20Folder/Container\% 20plastics\%20estimate.pdf>.

Teuten, E.L., J.M. Saquing, D.R. Knappe, M.A. Barlaz, S. Jonsson, A. Björn, S. Rowland, R. Thompson, T. Galloway, R. Yamashita, D. Ochi, Y. Watanuki, C. Moore, P. Viet, T. Tana, M. Prudente, R. Boonyatumanond, M. Zakaria, K. Akkhavong, Y. Ogata, H. Hirai, S. Iwasa, K. Mizukawa, Y. Hagino, A. Imamura, M. Saha, and H. Takada. 2009. Transport and release of chemicals from plastics to the environment and to wildlife. Philosophical Trans. Royal Soc. B Biol. Sci. 364:2027-2045.

U.S. Environmental Protection Agency. 2014. Plastics. 22 Sept. 2014. <http:// www.epa.gov/wastes/conserve/materials/ plastics.htm>.

Yeager, T.H. 2003. Implementation guide for container-grown plant interim measure. Univ. Florida, Inst. Food Agr. Sci., Florida Coop. Ext. Serv., Environmental Hort. Dept. ENH-895. 